\title{
Visita de los profesores Lorenzo Perrone y Anders-Christian Jacobsen
}

\author{
Samuel Fernández \\ FACULTAD DE TEOLOGÍA \\ PONTIFICIA UNIVERSIDAD CATÓLICA DE CHILE
}

Entre el 4 y el 13 de abril de 2017 nuestra Facultad recibió la visita de dos destacado profesores europeos: Lorenzo Perrone, Profesor del Dipartimento di Filologia Classica e Medioevale de la Universidad de Bolonia, Italia y Anders-Christian Jacobsen, Profesor de Teología Sistemática de School of Culture and Society de la Universidad de Aarhus, Dinamarca. Ambos son activos investigadores de los textos origenianos, Perrone ha editado y estudiado las 27 homilías de Orígenes sobre los Salmos, descubiertas en el Codex Monacensis Graecus 314 (Origenes Werke, Band XIII. Die neuen Psalmenhomilien. Die Griechischen Christlichen Schriftsteller der ersten Jahrhunderte, Neue Folge, 19, Berlin 2015), mientras Jacobsen desarrolla un importante proyecto de investigación, The History of Human Freedom and Dignity in Western Civilization, en conjunto con seis universidades, que busca describir el proceso de recepción de la antropología de Orígenes en la cultura occidental (proyecto financiado por la Unión Europea, Marie Skłodowska-Curie grant agreement No. 676258).

El miércoles 5 de abril en la Casa Central de nuestra universidad, Anders-Christian Jacobsen ofreció una conferencia en la que expuso los resultados de su grupo de investigación, destacando de qué modo la antropología origeniana, centrada en la dignidad humana y en el libre albedrío, ha servido a lo largo del desarrollo de la cultura occidental, como un correctivo a la visión del hombre, propia de la tradición augustiniana, que pone el énfasis en que, a causa del pecado, el ser humano ha quedado dañado en su libertad y en su dignidad. Esta tensión entre dos visiones del ser humano, con acentos opuestos, se revela como 
una clave de lectura muy importante para comprender diversos momentos claves de la configuración de la cultura occidental. Esta conferencia, además, fue la primera actividad pública del recientemente constituido Grupo de Estudios de la Antigüedad, conformado por académicos de las facultades de Derecho, Filosofía, Letras, Historia y Teología de nuestra Universidad. Esta conferencia inaugural fue presidida por el Rector, Ignacio Sánchez.

El miércoles 12 de abril, ya en el contexto de la Semana Santa, el profesor Perrone, dictó la segunda conferencia organizada por el Grupo de Estudios de la Antigüedad. La actividad se realizó en el Hall de la Facultad de Teología. La conferencia se centró en la oración de Jesús en Getsemaní, según Orígenes. Perrone ofreció un recorrido por los textos que provienen de diferentes obras de Orígenes en que el maestro alejandrino desarrolla el significado de la agonía de Jesús en el huerto. Entre los diferentes textos, tiene particular relevancia los que provienen de las homilías sobre los Salmos recientemente descubiertas. La contemplación teológica de la oración de Jesús re- viste una particular importancia, porque permite adentrarse en la manera como Orígenes comprende la relación entre la humanidad y divinidad de Cristo, y la relación entre el Hijo y el Padre. Lorenzo Perrone ha venido ya varias veces a nuestra Facultad y afirmó: «Mis estadías aquí han sido siempre una oportunidad preciosa para ampliar los conocimientos y estrechar contactos científicos y amistades».

Además de estas actividades públicas, los profesores Perrone y Jacobsen realizaron otros encuentros académicos. También conversaciones grupales y personales con estudiantes de Magíster y Doctorado, de un almuerzo con las autoridades de la Facultad de Teología, tal vez el encuentro más importante fue con el grupo del Proyecto Fondecyt, Relectura de la "crisis arriana" como "crisis monarquiana», en que además de los investigadores, participaron un buen grupo de estudiantes de pre y post grado que colaboran de diferentes formas en la investigación. Ambas visitas contribuyeron al desarrollo del área patrística y a la profundización de nuestras redes de colaboración académica internacional. 